\title{
Identification of Conversation-based Audio Recordings Between Co- Car Drivers and Passengers
}

\author{
1Wahyu Setiawati \\ ${ }^{1}$ Mataram University, Mataram, Indonesia \\ wahyusetiawati@gmail.com
}

\begin{tabular}{|c|c|}
\hline Article Info & Abstract \\
\hline $\begin{array}{l}\text { Article History } \\
\text { Received: July 12, } 2018 \\
\text { Accepted: September 30, } \\
2018\end{array}$ & \multirow{2}{*}{$\begin{array}{l}\text { Go-Car is part of Go-Jek service that provides varied online services to its } \\
\text { passengers. In this paper, the driver is the part of its online taxi service. The } \\
\text { aim of this paper is to find out the types of identity that appear during a } \\
\text { short conversation between a Go-Car driver and the passengers. The paper } \\
\text { used the framework of conversational identity to examine the twelve-minute } \\
\text { audio recording of the conversation to find the type of identity that is } \\
\text { negotiated in driver's talk. The conversation is situated naturally in the road } \\
\text { to Mataram city. As the results, two types of identity appeared in Go-Car } \\
\text { Driver's talk, namely, personal identity and collective identity. The personal } \\
\text { identity expression could be seen from the way the driver showing his status } \\
\text { as a bank staff and a highly paid Go-Car driver. }\end{array}$} \\
\hline $\begin{array}{l}\text { Keywords } \\
\text { Identity; Personal Identity; } \\
\text { Collective Identity; Go-Car }\end{array}$ & \\
\hline $\begin{array}{l}\text { Support by: } \\
\text { doi) Crossref }\end{array}$ & This is an open access article under the CC-BY-SA license \\
\hline
\end{tabular}

\section{INTRODUCTION}

Language is essential for human. It is almost impossible for human to live without language. As a social creature, human uses language as both interactional and transactional tools. Language is also a strong representation of human culture. In some ways, culture shapes the language use. Sometimes, certain use of language carries certain meaning and represent a certain culture. As humans are created differently, they are gifted with different features, personalities, and languages. That makes every human has their own identity. There are many ways that are used to show and differentiate their identity. One way that is commonly done is by using language. To reveal their identity or to construct the identity that they desired to others, human is using language.

Identity has been studied for a long time ago. It is considered as an interesting subject to be examined since raising of different belief about identity appears, that is; identity is reflected naturally in the language that people use or the people constructed their identity by the language they used. Nowadays, many types of research about identity have been conducted. There are some types of identities that can appear includes individual identity, or group identity, and even ethnic identity.

In everyday talk, people bring with them the identity that they believe they have. Sometimes, they also construct the identity based on the situation and audience that is involved in the interaction. The analysis of discourse enables the researcher to dig and evaluated the type of identity that people bring in their interaction with others.

This paper examined the identity of the Go-Car driver that exists during a short conversation between a Go-Car driver and the passengers. Go-Car is part of Go-Jek service. It is an online service provider. The service that is available in Go-Jek is varied. 
In this paper, the driver is the part of its online taxi service. The aim of this paper is to find out the types of identity that appear during that conversation.

\section{METHOD}

This paper used the descriptive qualitative method. By using this method, the data is being analyzed and presented based on its quality. In collecting the data, 12 minutes of audio recording is made during a conversation between Go-Car driver and the passengers in the Mataram city.

Go-Car is a part of Go-Jek service which offers online taxi with a fixed price provided for every destination. People who want to use the Go-Car service can order online via the Go-Jek application provided on the app-store on every Smartphone. The id of the passenger and the driver is listed in the application though it is not always correct. In analyzing the data, the audio recording is first transcribed into transcript then the text is analyzed to find the way in which the driver introduces his identity to the passenger.

\section{RESULT}

In the previous section, some relevant of literature is reviewed. Two types of identity found in human interaction are personal and collective identity. In this section, there are five extracts from a conversation between a Go-Car driver and his passengers that are analyzed based on that framework.

\section{Personal Identity}

As mention in the before, Personal identity is. In the below extract the Go-Car driver is negotiating his professional identity.

\section{Extract 1}

FP : Ooo harus ngambil ke bank?

So it has to be taken from the bank?

$D$ : Enggak, deposit kita ditransfer ke virtual accountnya di sini, ntar ditransfer ke rekening kita sih, tapi nunggu enam jam. Enam jam, besok pagi berarti. Ahahaha. Enak kok di sini, iseng-iseng lumayan.

No, our deposit is transferred to the virtual account here, then it will be transferred to our bank account, but we have to wait for four hours. Four hours means tomorrow morning. Ahahaha. It's good here, leisurely but pretty good.

FP : Berarti mas iseng-iseng aja ya jadi driver? So you are being a driver just leisurely?

$D$ : Iya iseng-iseng, saya aslinya di bank mba Yes, leisurely, I actually work in the bank sis.

FP : Wahl ken kilo di bank gimping ngambil uangnya langsung ambil aja Wah, if you work in the bank it is easy to take the money, just take it directly.

$D$ : Ahahahaha iya sih Ahahahha it is.

In the conversation, the Go-Car driver emphasizes that he is not taking the job as a driver for seriously. He just does it leisurely. It is widely known that in Indonesia, NTB especially, the job as a paid driver often seen as a lower middle social class of job. Therefore he is negotiating this identity and stating that he is actually worked in the bank. Perhaps, he believes that the society sees the bank staff as a prestigious job that earns a lot of many. The driver might do this (stating that he is actually worked in the bank) to make the passenger admire him as he assumes that the passenger also shares the same perspective with the society. 


\section{Extract 2}

FP : Lumayan ya, itu point bisa dipake apa aja ya?

It is pretty good, what is the point for?

$D$ : Enggak, targetnya

No, it is the target

FP : oooo

$D \quad$ : Ya kan kalo targetnya 12 point itu dapet 300 ribu

So the target is 12 points to get $300 \mathrm{~K}$

FP : Itu per apa?

For what period?

D : Per hari........... Kalo 7 itu 75 ribu, 9 point ditambah 100 jadi 175, kalo tembus 12 ditambahin lagi 125 jadi 300

Per day, if 7 points got $75 \mathrm{k}, 9$ points is added with 100 become 175, if you make it (points) it will be added with 125 more so it becomes 300 (300 thousand rupiah)

FP : Itu harus banyak banget donk ordernya

So it must be so many orders.

$D \quad$ : Iya mba, kemarin aja hari minggu itu saya dapet 750 itu Yes sis, yesterday on Sunday I got 750 (750 k rupiah)

FP : Wow Wow

D : Hahahaha keliatannya aja sepele mbak tapi banyak duitnya Hahahaha it is only the look that it is trivial, but it earns a lot of money.

The underlined statements or sentence chunks on the extract two above shows that the driver is explaining to the passenger that driver is not a trivial money producer. Rather, it can produce a lot of money too. In this case, the driver is trying to construct his identity as a driver that earns a lot of money. This construction also can be seen in the following extract

\section{Extract 3}

FP : Mas install Go-Jek doank ya?

Bro, you are only installing Go-Jek, aren't you?

$D \quad$ : Iya, Go-Car aja, kalo dua bingung ntar, ini aja udah lumayan mbak, 4 hari dapet berapa saya, hampir dua juta, mulai dari hari jumat kemarin

Yes, only Go-Car, if two then it will be confusing, this is already quite a lot sis, how much did I get in 4 days, almost two million, started from yesterday Friday.

FP : Lumayan banyakjuga

Quite a lot too.

$D$ : Eh jumat, sabtu. Sabtu, minggu senin selasa. Iya, dapet dua juta. Iseng-iseng berhadiah

Eer.. Friday, Saturday. (looks like he is counting the day to make sure that four days is started from Friday but he wrongly predicted it so he repeats his statements). Saturday, Sunday, Monday, Tuesday. Yes, got two million. Leisure and prized.

In line two and three of the extract 3, the driver stated that he go two million in four days. if it is true, it is a fantastic amount of money that a driver could earn in NTB since the minimum average salary in this province is only about 1,8 million rupiah per month. By giving this sort of explanation the Go-Car driver now is constructing the new identity of a highly paid driver. It has become a common thing in a city that someone with a 
highly paid job is more respected by others than the one who doesn't. In line 5 and 6 of the extract 3 , he is also once again restating that this an easy but worth it job.

Therefore, from the analysis of the three extracts above, it can be seen that the GoCar Driver is constructing and negotiating some personal identity, namely, his identity as a bank staff, and a highly paid Go-Car driver.

\section{Collective identity}

In the previous analysis, it has been shown that the Go-Car driver is negotiating his personal identity. However, in the next extract, it seems that he is also negotiating other identities that are collective identity. In the following extract, this collective identity is reflected.

\section{Extract 4}

FP : Kalo dulu saya pernah nemu ada supir driver itu dia nginstall tiga app yang beda In the past, I met a driver who installed three different apps.

$D$ : Uber, Grab, Go-car?

$F P$ : Iya

Yes

D : Ahahahaha,, ntar tiga-tiganya masuk orderan itu bahaya Ahahaha.. then if three have incoming order it is dangerous

FP : Nah jadi itu kalo satu masuk yang lain langsung dimatiin Nah so if one order is coming, the other (app) is turned off directly.

$D$ : Kayak kita ini mbak ya kalo ada yang iseng-iseng ngorder terus dicancel itu ee sedih udah drivernya itu, performanya turun, soalnya nyakit, kalo dua yang cancel kita harus cari 4.

It is like us sis, if there is someone who is not seriously ordering and then cancel the order, it is sad. The driver performance (on the app) is decreased because it hurts, if two people cancel the orders, we have to find four (orders)

In line 6 and 7 of the extract 4, the driver addresses himself as "us" and "we". This shift from the use of addressee 'I' to 'us' and 'we' shows that he is constructing a collective identity as part of the Go-Car driver, and not another online brand of a taxi. He is placing himself as having the same feeling of sadness as the other Go-Car Drivers if the taken orders are canceled. This clearly reflects his sense of belonging to the certain group of community, namely, Driver of Go-Car.

Another collective identity is also found in his conversation with the passenger. The following extract is provided to explain what type of collective identity that he has.

\section{The extract 5}

D : Minimal 50, kalo yang pertama kali ngisi itu orang ngisi 50 ribu kita dapet 3 point, orang yang pertama kali pake aplikasi go-car. Enak mbak, banyak driver ceweknya, banyak

Minimum 50, if it is the first time the passenger top up $50 \mathrm{~K}$ we got 3 points. The person who uses the Go-Car application for the first time. It good sis, there is a lot offemale drivers too $A$ lot

FP : Saya nggak pernah nemu sih driver cewek

I never meet the female driver

$D$ : Iya, tapi mereka cepet-cepet targetnya, focus soalnya, dari pagi dia paling siang itu udah target, saya ini baru keluar tadi, paling nyari 7 aja ni, lumayan Yes, but they got the target fast because they focus, from the morning, only in about the noon they reach the target, I just came out earlier only look for 7 (points), it's not bad. 
The underlined words in line two and five of the extract five mention the notion of a female. The driver states that besides male there is also a female driver. He constructs the identity of this female driver as a driver that focus on the target and therefore the reach the target faster. He tries to differentiate himself from the female driver group in which he mentions that inline six of the extract 5. He emphasizes that "I just came out earlier, only look for 7 (points)". This is the way he negotiates his identity as being a part of the male driver because he is not focused. He brings out the common belief about the nature of female in Lombok, that female is more focus that man.

Therefore, because he just being a driver leisurely and just worked for a few hours before the conversation, he is showing that he does not have that female driver nature. He probably classifies himself as a male driver category and making this a collective gender identity of masculine.

The result of the analysis of the collective identity in the conversation shows that there are two types of collective identity found in the driver's talk. These collective identities are Go-Car drivers' identity and masculine identity.

\section{CONCLUTION}

After analyzing the conversation, it is found that there are two types of identities that is appears in Go-Car Driver's talk, namely, personal identity and collective identity.

The personal identity, from the analysis of the three extracts above, it can be seen that the Go-Car Driver is constructing and negotiating some personal identity, namely, his identity as a bank staff, and a highly paid Go-Car driver.

The result of the analysis of the collective identity in the conversation shows that there are two types of collective identity found in the driver's talk. These collective identities are Go-Car drivers' identity and masculine identity.

\section{REFERENCE}

[1] Abell, Jakie. Stokoe, Elizabeth. 2001. Broadcasting the royal role: Constructing culturally situated identities in the Princess Diana Panorama interview. British Journal of Psychology.

[2] Heritage, J. 2005. Conversation analysis and institutional talk - Handbook of language and social interaction. Online Journal

[3] Jackson, Ronald L. Hogg, Michael A. 2010. Encyclopedia of Identity, Volume 1.SAGE

[4] Malone, Martin J. 1997. Worlds of Talk: The Presentation of Self in Everyday Conversation Polity Press.

[5] McKinlay, A. McVittie, C. 2008. Social Psychology and Discourse.

[6] Mead, George Herbert. 1934. Mind, Self, and Society. University of Chicago Press.

[7] Oyserman, Daphna. Elmore, Kristen. Smith, George. 2012. Self, Self-Concept, and Identity. Journal Article

[8] Polletta, Francesca, and Jasper, James M. 2001. Collective Identity and Social Movements. Annual Review of Sociology

[9] Versluys, Eline. 2008. The Notion of Identity In Discourse Analysis: Some 'Discourse Analytical' Remarks. Journal Article. 